\title{
Simultaneous removal of COD and color from municipal landfill leachate using Ozone/Zinc Sulphate oxidation process
}

\author{
Salem S. Abu Amr ${ }^{1}$, Hamidi Abdul Aziz ${ }^{2,3,}{ }^{,}$, Md. Sohrab Hossain ${ }^{1}$, Mohammed J.K. Bashir ${ }^{4}$ \\ ${ }^{1}$ Malaysian Institute of chemical \& Bioengineering Technology, Universiti Kuala Lumpur, (UniKL, MICET), 78000, Melaka, Malaysia \\ ${ }^{2}$ School of Civil Engineering, Engineering Campus, Universiti Sains Malaysia, 14300 NibongTebal, Penang, Malaysia \\ ${ }^{3}$ Solid Waste Management Cluster, Science \& Engineering Research Centre (SERC), Engineering Campus, Universiti Sains Malaysia, 14300 \\ Nibong Tebal,Penang, Malaysia \\ ${ }^{4}$ Department of Environmental Engineering, Faculty of Engineering and Green Technology, Universiti Tunku Abdul Rahman, 31900 \\ Kampar, Perak, Malaysia. \\ Received: 14/03/2017, Accepted: 19/09/2017, Available online: 23/10/2017 \\ *to whom all correspondence should be addressed: e-mail: cehamidi@eng.usm.my
}

\begin{abstract}
Municipal landfill leachate generated from aged sites requires an efficient treatment to minimize the high level of refractory organic matters prior to final discharge. In the current study, the performance of combined ozonation and Zinc sulfate $\left(\mathrm{ZnSO}_{4}\right)$ for anaerobic stabilized leachate treatment was investigated. The efficiency of $\mathrm{Zn}$ dosage $\left[\mathrm{COD}_{0} / \mathrm{Zn}\right.$ ratio $\left.(\mathrm{g} / \mathrm{g})\right], \mathrm{pH}$, and ozonation time was evaluated. The optimal removal efficiencies for COD and color were $90 \%$ and $99 \%$, respectively at $1 \mathrm{~g} / 6 \mathrm{~g} \mathrm{ZnSO}_{4}$ dosage $\left(\mathrm{COD}_{0} / \mathrm{Zn}\right), \mathrm{pH} 4$, and $180 \mathrm{~min}$ reaction time. However, the performance of $\mathrm{O}_{3} / \mathrm{Zn}$ oxidation process in removing ammoniacal nitrogen from leachate was not efficient as less than 5\% removal for ammonia was obtained. The results revealed that the performance of the new catalytic ozone method (i.e., $\mathrm{O}_{3} / \mathrm{Zn}$ ) in removing removal organic substances from leachate was higher than another related oxidation process such as $\mathrm{O}_{3} /$ Fenton and $\mathrm{O}_{3} /$ persulfate.
\end{abstract}

Keywords: Ozonation, Zinc sulfate, Anaerobic stabilized leachate, Removal, Treatment

\section{Introduction}

There is increasing environmental pollution concerns on the safe disposal of Municipal solid waste (MSW). The percolation of rainfall in combination with the decomposition of landfilled solid waste generates highly contaminated liquid, called "leachate" (Aziz et al., 2010). The high quantity of polluted leachate produced from landfilling MSW is causing high potential hazard on the surrounding soil, surface water and public health. Leachate contains large amounts of dissolve organic matter, inorganic ions like ammonia; heavy metals and other biological substances (Ghafari et al., 2010; Shehzad et al., 2015). The leachate characterization depends on various factors including amount of leachate generation, physicochemical compositions, age of the landfill, seasonal weather variations and climate of the site (Aziz et al., 2010).
However, age and type of landfill are among the most important factors that affect leachate characterization. Studies reported that the stabilized leachate from old landfills ( $>10$ years) contains extremely high organic content, high ammonia and low biodegradability $\left(\mathrm{BOD}_{5} / \mathrm{COD}<0.1\right)$ (Schiopu and Gavrilescu, 2010; Bashir et al., 2015).

Leachate requires an efficient treatment to minimize the high level of pollutants prior to final discharge (Aziz et al., 2010; Azmi et al., 2016). In recent years, several technologies have utilized to minimize the hazards of mature landfill leachate like coagulation/flocculation, adsorption using activated carbon, ion exchange, and advance oxidation techniques (Abu Amr and Aziz, 2012; Abu Amr et al., 2013; Bashir et al., 2011). Biological treatment is low cost and environmental friendly method for landfill leachate, when compare with the others treatment options (Bila et al., 2005). However, the biological treatment process shows inefficient treatment of landfill leachate such as incomplete mineralization. In recent years, the advance oxidation process (AOP) is extensively utilizing leachate treatment because of its effectiveness against complex organic matter ( $\mathrm{Li}$ et al., 2010). Among various advance oxidation processes, Ozonation is one of the chemical processes, which involves the utilization of ozone to treat water and wastewater for the removal pollutants (Tizaoui et al., 2007). Ozone is a powerful oxidizing agent at an oxidizing potential of 2.08 $\mathrm{eV}$, react with organic matter either directly or indirectly through $\mathrm{OH}^{*}$ radical (Goi et al., 2009; Hagman et al., 2008; Tizaoui et al., 2007). The application of ozone in wastewater treatment has recently received attention due to its potential advantages (Goi et al., 2009; Bila et al., 2005; Baig and Liechti 2001; Huang et al., 1993). These advantages are including high efficiency on removing color and the degradation of the organic matter, easy installation, no chemical residue and sludge generation (Abu Amr et al., 2013). 
In spite of several advantages offers by the ozonation of wastewater, there are some disadvantages which limits the application of ozone in large scale wastewater treatment. The distinct disadvantages are low solubility in water e.g., $0.57 \mathrm{gL}^{-1}$ at ambient temperature, low stability with a halflife of about $20 \mathrm{~min}$ at neutral $\mathrm{pH}$ and ambient temperature, high energy requirement for ozone production which is about 12 to $18 \mathrm{kWh}^{-1}$, and the partial oxidation of the organic matters present in the wastewater either directly or by molecular ozone (Langlais et al., 1991; Lenntech, 2016). To overcome existing limitation of advance oxidation processes, environmentalists have promoted various methods for in-situ oxidization via indirect action of ozone on the organic materials with an elevated oxidation potential. For instance, Mehrjouei et al. (2015) summarized the performance of photocatalytic ozonation for the treatment of waste and wastewater. Cong et al., (2015) enhanced ozonation of parachlorobenzoic acid in liquid medium by using peroxymonosulfate. Recently, ozonation received attention for stabilized leachate treatment. Several application using ozone based advanced oxidation processes have been conducted for stabilized leachate treatment. Abu Amr et al. (2012, 2013 and 2016) used Fenton, persulfate and zirconium tetrachloride $\left(\mathrm{ZrCl}_{4}\right)$ to improve ozonation in stabilized leachate treatment, respectively. Tizaoui et al., (2007) employed $\mathrm{H}_{2} \mathrm{O}_{2}$ to enhanced ozonation of old landfill leachate. Rivas et al 2003 employed ozone and activated carbon for stabilized leachate treatment. Several oxidation processes have been applied on stabilized leachate treatment using factorial design and optimization to optimize the experimental conditions and asses the statistical relationship between factors and responses (Table 2). Studies have also utilized various transition metal compounds and determined catalytic activities on the oxidation (catalytic ozonation) of organic matter in wastewater (Chen and Wang; 2014; Sun et al.,2014; Zhu et al., 2014; Mehrjouei et al., 2015). Chen and Wang, (2014) determined the catalytic activity of $\mathrm{TiO}_{2} / \alpha-\mathrm{Al}_{2} \mathrm{O}$ catalysts towards the in ozonation of natural organic matter. Sun et al., (2014) utilized $\mathrm{MnO}_{\mathrm{x}} / \mathrm{SBA}-15$ to improve the ozonation of oxalic acid in aqueous solution. Zhu et al. (2014) employed a catalytic chip containing $\mathrm{CuO}$, $\mathrm{ZnO}, \mathrm{Al}_{2} \mathrm{O}_{3}$, and $\mathrm{ZrO}_{2}$ in the catalytic ozonation of basic yellow 87 removals in wastewater. However, it was observed that catalytic ozonation attains elevated rates of organic materials mineralization, particularly, in an acid medium. Catalytic ozonation is considered as a homogeneous treatment process due to the activation of the ozone by the metallic ion (s) presents in aqueous solution.

Among the various metallic compounds, Zinc sulfate $\left(\mathrm{ZnSO}_{4} .7 \mathrm{H}_{2} \mathrm{O}\right)$ has been investigated as a coagulant and found very effective in various wastewater treatments (Ho et al., 2002). The performance of zinc sulfate in impoving ozone oxidation of organic materials in wastewater was not investigated. It is thereofore, the present sudy was undertaken to determine the influences of zinc sulfate in ozonation of organic matter in anaerobic stabilized leachate. Wherein, the influences of zinc sulfate in ozonation of organic matter were evaluated based on the removal of $\mathrm{COD}$ and color with varying $\mathrm{ZnSO}_{4} .7 \mathrm{H} 2 \mathrm{O}$ dosages, $\mathrm{pH}$ and reaction time.

\section{Materials and methods}

\subsection{Leachate sampling and characteristics}

Leachate samples that used in this study were collected from Alor Pongsu Landfill Site (APLS), Alor Pongsu, Perak, Malaysia. APLS is classified as an anaerobic stabilized landfill for municipal waste disposal. The landfill is located at $5^{\circ} 04^{\prime} \mathrm{N}, 100^{\circ} 35^{\prime} \mathrm{E}$ coordinates. APLS started receiving waste in 2000. Since then the landfill received around 660,000 metrics tons of domestic waste, which is approximately 200 metric tons per day (Zawawi et al., 2011) and still working until the current date. In this study, the leachate was manually collected for five times using 20 L plastic containers within September 2014 to March 2015. The samples collected were immediately brought to the laboratory for the characterization. The samples were then stored in a refrigerator at $4{ }^{\circ} \mathrm{C}$ to minimize biological and chemical reactions. The physic-chemical compositions of the leachate are summarized in Table 1.

Table 1. General characteristics of leachate from APLS

\begin{tabular}{cccc}
\hline Parameters & Min. & Max. & $\begin{array}{c}\text { Value } \\
\text { (average) }\end{array}$ \\
\hline $\mathrm{COD}(\mathrm{mg} / \mathrm{L})$ & 2180 & 4250 & $3350 \pm 96$ \\
\hline $\mathrm{BOD}_{5}(\mathrm{mg} / \mathrm{L})$ & 199 & 348 & $274 \pm 3$ \\
\hline $\mathrm{NH}_{3}-\mathrm{N}(\mathrm{mg} / \mathrm{L})$ & 1450 & 1897 & $1674 \pm 24$ \\
\hline Color $(\mathrm{Pt} \mathrm{Co})$ & 4650 & 20300 & $11400 \pm 187$ \\
\hline $\mathrm{pH}$ & 7.93 & 8.64 & $8.29 \pm 0.04$ \\
\hline Conductivity, $(\mu \mathrm{S} / \mathrm{cm})$ & 8208 & 13367 & $10788 \pm 256$ \\
\hline Temperature $\left({ }^{\circ} \mathrm{C}\right)$ & 28.1 & 30.2 & $29.2 \pm 1$ \\
\hline Dissolved Oxygen $(\%)$ & 1.1 & 8.5 & $4.8 \pm 0.2$ \\
\hline Dissolved Oxygen $(\mathrm{mg} / \mathrm{L})$ & 0.09 & 0.64 & $0.37 \pm 0.06$ \\
\hline Total Dissolved Solid $(\mathrm{mg} / \mathrm{L})$ & 4855 & 8110 & $6483 \pm 112$ \\
\hline Salinity (ppt) & 4.08 & 7.11 & $5.60 \pm 0.5$ \\
\hline
\end{tabular}

\subsection{Experimental procedures}

The experiments in this study were performed using leachate sample volume of $500 \mathrm{~mL}$. The ozone reactor used in this study designed with $20 \mathrm{~cm}$ height and $8 \mathrm{~cm}$ inner diameter (Fig. 1). A cross-column ozone chamber was placed in the reactor to enhance the ozone gas diffusion. Using a water bath and cooling system, the internal reaction temperature of the reactor was maintained at below $15^{\circ} \mathrm{C}$, which is the optimal condition to maintain the half-life of dissolved $\mathrm{O}_{3}(30 \mathrm{~min}$ ) in water (Block and Brown, 2004). BMT 803 generator (BMT Messtechnik, Germany) was utilized to generate ozone gaze using pure dry oxygen. The follow rate of the generated ozone gas was adjusted at $1,000 \mathrm{~mL} / \mathrm{min} \pm 10 \%$ to generate $\mathrm{O}_{3}$ concentration with 27 $\mathrm{g} / \mathrm{m}^{3}$ at 1 bar of pressure. The concentration of ozone gaze was measured using an ultraviolet gas ozone analyzer (BMT 964). Zinc sulfate $\left(\mathrm{ZnSO}_{4} .7 \mathrm{H}_{2} \mathrm{O}\right)(\mathrm{M}=287.54 \mathrm{~g} / \mathrm{mol})$ was used to improve ozonation during the oxidation of leachate (Fig. 1). 


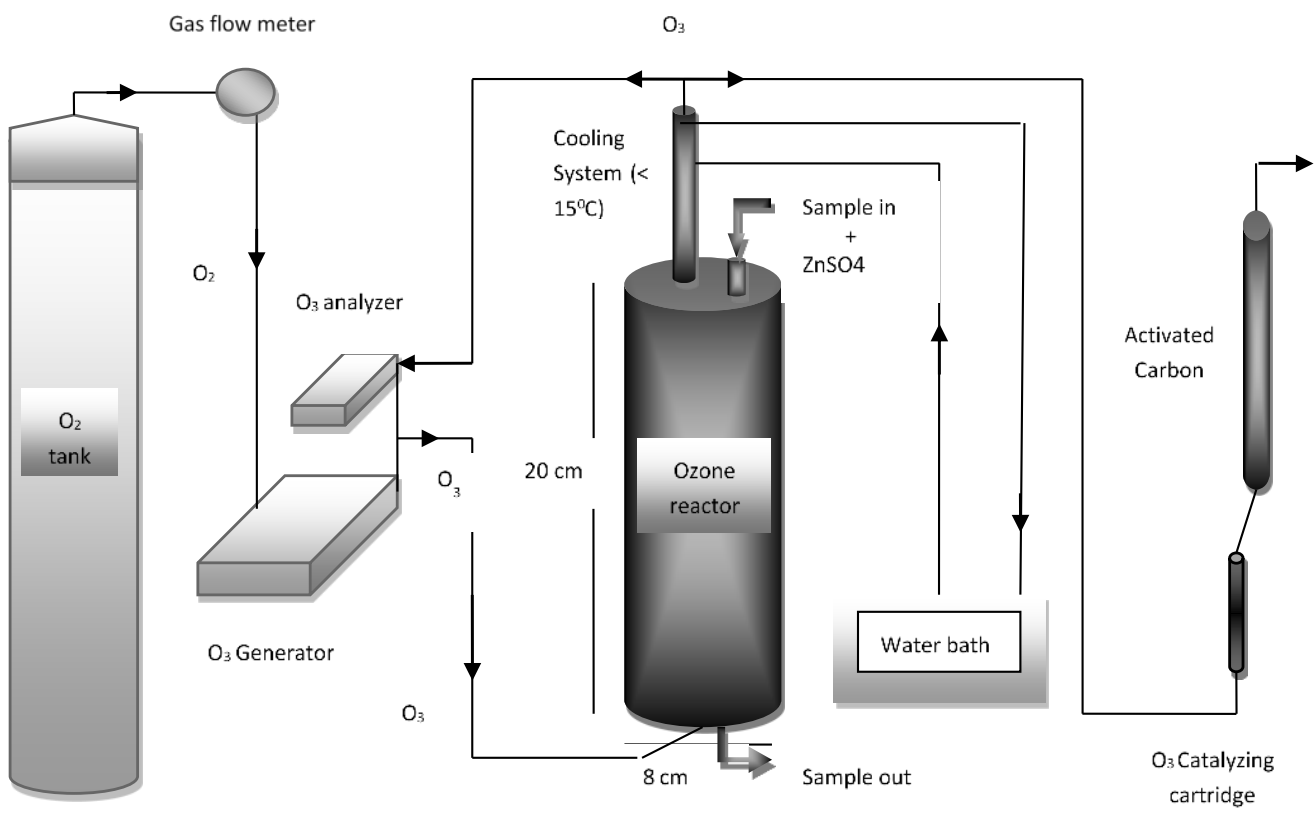

Figure 1. Schematic diagram of ozonation procedures

A set of experiments were performed to obtain the optimal operation conditions of the variables, such as $\mathrm{ZnSO}_{4} .7 \mathrm{H}_{2} \mathrm{O}$ dosages, $\mathrm{pH}$ and reaction time on the recovery of COD and color from stabilized landfill leachate. At first, the influences of $\mathrm{ZnSO}_{4} .7 \mathrm{H}_{2} \mathrm{O}$ dosage was determined with varying $\mathrm{COD} / \mathrm{Zn}^{2+}\left(\mathrm{COD} / \mathrm{Zn}^{2+}, \mathrm{g} / \mathrm{g}\right)$ ratios. Desired amount of $\mathrm{ZnSO}_{4} .7 \mathrm{H}_{2} \mathrm{O}$ and $500 \mathrm{~mL}$ of leachate was taken into the ozone reactor and allowed to react for $60 \mathrm{~min}$ at natural leachate $\mathrm{pH}$ of 8.05. Subsequently, the effect of the initial $\mathrm{pH}$ on $\mathrm{COD}$ and color removal was determined by varying $\mathrm{pH}$ from $\mathrm{pH} 3$ to $\mathrm{pH} 11$ at optimal $\mathrm{ZnSO}_{4} .7 \mathrm{H}_{2} \mathrm{O}$ dosages (i.e., $1 \mathrm{~g} / 2 \mathrm{~g} \mathrm{COD} / \mathrm{ZnSO}_{4} .7 \mathrm{H}_{2} \mathrm{O}$ ) for the ozonation time of $60 \mathrm{~min}$. The $\mathrm{pH}$ of the leachate sample was adjusted $5 \mathrm{M}$ of sulfuric acid and sodium hydroxide solutions. Finally, the influences of ozonation time on the removal of COD and color was optimized with varying reaction time from $30 \mathrm{~min}$ to 240 min at optimal $\mathrm{ZnSO}_{4} .7 \mathrm{H}_{2} \mathrm{O}$ dosages (i.e., $1 \mathrm{~g} / 2 \mathrm{~g} \mathrm{COD} / \mathrm{Zn}^{2+}$ ) and $\mathrm{pH}$ (i.e., $\mathrm{pH} 4$ ).

After each run, the sample was allowed to settle for $1 \mathrm{~h}$ at $\mathrm{pH} 6$ prior to further analysis. In order to evaluate the performance of combined ZnSO4/ozonation process on the simultaneous removal of COD and color from anaerobic stabilized leachate, the leachate sample was treated by $\mathrm{ZnSO}_{4} .7 \mathrm{H}_{2} \mathrm{O}$ and ozone separately, zinc sulphate coagulation was performed in a $500 \mathrm{~mL}$ sample volume reactor, using (1g/6g CODo/ $\left.\mathrm{Zn}^{2+}\right) \mathrm{ZnSO}_{4}$ dosage, at $\mathrm{pH}$ 6, rapid mixing with $250 \mathrm{rpm}$ during $5 \mathrm{~min}$ followed by $60 \mathrm{rpm}$ for 30 min (slow mixing) then, the sample was settled for 25 min (Gafari et al., 2005).

\subsection{Analytical methods}

The concentration of COD and color were determined before and after each experiments by using a DR 2800 $\mathrm{HACH}$ spectrophotometer. Leachate sample was mixed well before analysis. $\mathrm{pH}$ of the sample was measured by using a portable digital $\mathrm{pH} / \mathrm{Mv}$ meter. The removal efficiencies of COD, and color were calculated by using the following Eq 1:

$$
\% \text { Removal }=\frac{x_{i}-x_{f}}{x_{i}} \times 100
$$

where $x_{i}$ and $x_{f}$ refer to the initial and final COD and, color, respectively.

\section{Results and discussion}

\subsection{Effect of $\mathrm{ZnSO}_{4}$ dosages}

The influences of zinc sulphate on improving the ozonation was determined with varying zinc sulphate dosages at $\mathrm{pH}$ 8.05 (natural leachate $\mathrm{pH}$ ) for $60 \mathrm{~min}$. The results obtained are present in Fig.2. It was observed that zinc sulphate played an effetive role on increasing the removal of COD and color from the stabilized anaerobic leachate. The percentange COD and color removal of $4 \%$ and $22 \%$, resepectively, were gained at $\mathrm{COD} / \mathrm{Zn}^{2+}$ ratio of $1 / 0$ (only with $\mathrm{O}_{3}$ and in absence of $\mathrm{ZnSO} 4,7 \mathrm{H} 2 \mathrm{O}$ ). However, the percentage removal of COD and color increased rapidly with increasing zinc sulphate dosages upto the $\mathrm{COD} / \mathrm{Zn}^{2+}$ ratio of $1: 2$ ( $69 \%$ and $79 \%$, respectively), thereafter the increased of percentage COD and color removal was negligiable with zinc sulpahte dosages. The maximum removal COD and color were obtanied about $74 \%$, and $86 \%$, respectively, at $\mathrm{COD} / \mathrm{Zn}^{2+}(\mathrm{g} / \mathrm{g})$ ratio of $1: 6$.

\subsection{Effect of $\mathrm{pH}$}

The effect of $\mathrm{pH}$ on the removal of COD and color from the stabilized anaerobic leachate using zinc sulphate assisted ozonation process was determined, as presented in Fig.3. The influence of $\mathrm{pH}$ was dtermined with varying $\mathrm{pH} 3$ to $\mathrm{pH}$ 11 at $\mathrm{COD} / \mathrm{Zn}^{2+}(\mathrm{g} / \mathrm{g})$ ratio of 1:6 for $60 \mathrm{~min}$. It was found the removal of COD and color was slightly increased with increasing $\mathrm{pH}$ from $\mathrm{pH} 3$ to $\mathrm{pH} 4$, thereafter the removal of $\mathrm{COD}$ and color was found to decrease with increasing $\mathrm{pH}$ 
from $\mathrm{pH} 4$ to $\mathrm{pH}$ 11. The romoval of COD and color was obtained at $\mathrm{pH} 3$ were $75 \%$ and $93 \%$, respectively, those were slightly increased to $77 \%$ and $94 \%$ at $\mathrm{pH} 4$, respectively. Wherein, the romoval of COD and color was obtained at $\mathrm{pH} 11$ were $60 \%$ and $73 \%$. The highest COD and color removal of $77 \%$ and $94 \%$ were gained at $\mathrm{pH} 4$. Thus, the $\mathrm{pH} 4$ was determined to be the optimal $\mathrm{pH}$ for the zinc sulphate assisted ozonation process for the stabilized anaerobic leachate.

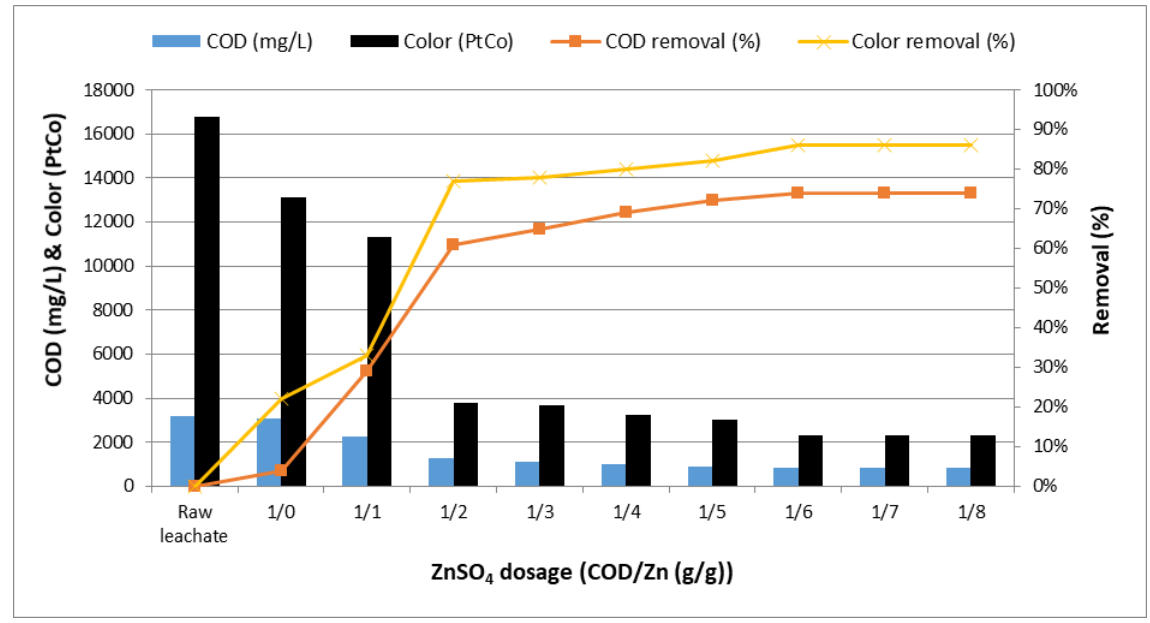

Figure 2. Effect of $\mathrm{ZnSO}_{4}$ dosage on $\mathrm{COD}$ and Color removal at $60 \mathrm{~min}$ ozonation of leachate, $\mathrm{pH} 8.05$ and $\mathrm{O}_{3}$ dosage $27 \mathrm{~g} / \mathrm{m}^{3}$

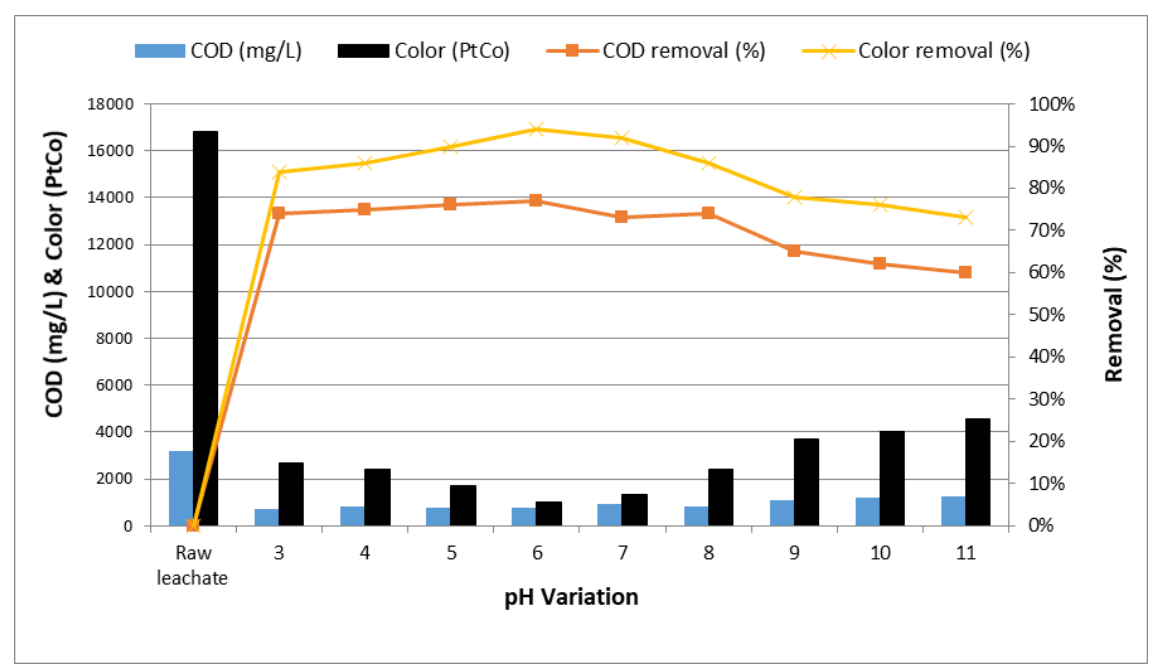

Figure 3. Effect of $\mathrm{pH}$ variation on $\mathrm{COD}$ and Color removal during $60 \mathrm{~min}$ ozonation of anaerobic stabilized leachate (RT: $60 \mathrm{~min}, \mathrm{ZnSO}_{4}$ dosage $1 \mathrm{~g} / 6 \mathrm{~g} \mathrm{COD} / \mathrm{Zn}^{+2} \mathrm{~g} / \mathrm{g}$ ), $\mathrm{O}_{3}$ dosage $27 \mathrm{~g} / \mathrm{m}^{3}$ )

\subsection{Effect of reaction time}

Fig. 4 shows the influence of the reaction time on COD and color removal from the stabilized anaerobic leachate at $\mathrm{COD} / \mathrm{Zn}^{2+}(\mathrm{g} / \mathrm{g})$ ratio of $1: 6$ and $\mathrm{pH} 4$. As can see in Fig.4, both $\mathrm{COD}$ and color removal increased with increasing reaction time and reached to maximum about $90 \%$ and almost $100 \%$ at reaction time of $150 \mathrm{~min}$ and $180 \mathrm{~min}$, respectively. However, the increase of the COD removal was negligiable with further increased of reaction time over $150 \mathrm{~min}$.

The increase the removal efficiency with increasing of zinc sulphate dosages at $\mathrm{pH} 8.05$ due to the generation of hydroxyl redical (Langlais et al., 1991; Tizaoui et al., 2007). Tizaoui et al., (2007) reported that the increased of ozonation of landfill leachate with $\mathrm{H}_{2} \mathrm{O}_{2} / \mathrm{O}_{3}$ in a alkaline medium might due to the effect of indirect oxidation caused by existing hydroxyl radicals (Tizaoui et al., 2007). The formation of Hydroxyl radicals can be express as shown in Eq. 2 and Eq. 3.

$$
\begin{aligned}
& \mathrm{H}_{2} \mathrm{O}_{2}+2 \mathrm{O}_{3}^{2-} \rightarrow \mathrm{OH}^{*}+3 \mathrm{O}_{2} \\
& \mathrm{HO}_{2}^{-}+\mathrm{O}_{3} \rightarrow \mathrm{HO}_{2}+\mathrm{O}_{3}
\end{aligned}
$$




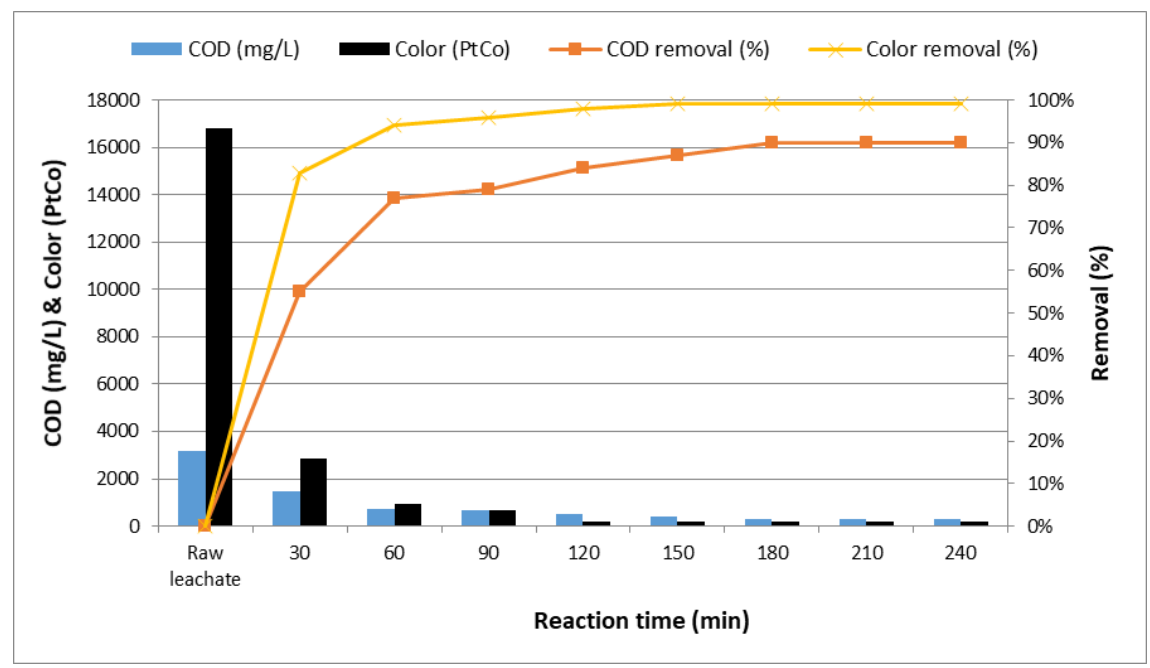

Figure 4. Effect of reaction time on $\mathrm{COD}$ and Color removal during ozonation of anaerobic stabilized leachate $\left(\mathrm{ZnSO}_{4}\right.$ dosage $1 \mathrm{~g} / 6 \mathrm{~g} \mathrm{COD} / \mathrm{Zn}^{+2}(\mathrm{~g} / \mathrm{g}), \mathrm{pH}(6), \mathrm{O}_{3}$ dosage $27 \mathrm{~g} / \mathrm{m}^{3}$ )

The effectiveness of ozonation in removing COD and Color were impoved by increasing the dosage of Zinc sulfate. Zinc sulfate can be hydroyzed in aqueous solution to zinc hydroxide (Eq 4 and Eq. 5), which contrepute to enhance ozone oxidation under the effect of hydroxyl radicals. Tizaoui et al. 2007 improved the removal efficiency of COD by utilizing hydrogen peroxide combined with ozone for leachate treatment. Abu Amr and Aziz (2012) used Fenton reagent to enhance ozonation of stabilized leachate.

$$
\begin{aligned}
& \mathrm{Zn}^{2+}+\mathrm{H}_{2} \mathrm{O} \leftrightharpoons+\mathrm{ZnOH}^{+}+\mathrm{H}^{+} \\
& \mathrm{Zn}^{2+}+2 \mathrm{H}_{2} \mathrm{O} \leftrightharpoons \mathrm{Zn} \quad(\mathrm{OH})_{\mathrm{q}}+2 \mathrm{H}^{+}
\end{aligned}
$$

$\mathrm{pH}$ plays an important role in controlling the ozonation kinetics. Ozonation may have two different reaction mechanisms at alkaline and acidic $\mathrm{pH}$ levels. In alkaline $\mathrm{pH}$ level, ozone decomposes to hydroxyl radicals, those have redox potential and un-selective nature. Whereas, in acidic medium ozone act as a direct ozonation process which has lower oxidation potintial $\left(E^{O}=2.07\right)$ than $\mathrm{OH} \cdot\left(E^{O}=2.80\right)$. Studies reported that the performance of ozonation in oxidizing organics in nature and alkaline $\mathrm{pH}$ is higher than that in in acidic medium under the efffect of hydroxil radical (Tizaoui et al., 2007). In the present study, it was observed that the ozonation performance was higher at $\mathrm{pH}$ 6 and 7. Moreover, the formation of $\mathrm{ZnOH}$ led to improve the oxidation potintial by generate additional amount of hydroxyl radicals. Coca et al. (2005) argued that hydroxide anions competed for ozone with organic materials in alkaline medium, which results in relatively higher COD and color removal. However, the removal of COD and color was reduced at $\mathrm{pH} 8$ and 9 (Figure 3).Tizaoui et al. (2007) reported that the effect of high hydroxyl group dosage led to inhibite the oxidation of ozone and reduced the removal effecincy of the organic materials in leachate. Another reason might inhibit the removal of COD and color from stabilized landfill leachate in alkaline medium is the increased of ozone decompositions into hydroxyl radicals in alkaline medium due to present of $\mathrm{Zn}^{2+}$. The decomposed hydroxyl radicals might generate oxygen or other less reactive species such as $\mathrm{HO}_{2}{ }^{*}$. The $\mathrm{HO}_{2}{ }^{*}$ radicals less reactive than hydroxyl radicals and might decompose to hydroxyl radicals in few steps, which results in slower degradation of organic materials present in leachate and hence minimize the COD and color removal in alkaline medium (Tizaoui et al., 2007; Rehman et al. 2012). The ozone deformation into oxygen and less reactive species in presence of $\mathrm{Zn}^{2+}$ in alkaline medium can be express as below:

$$
\begin{aligned}
& \mathrm{O}_{3}+\mathrm{OH}^{-} \stackrel{\mathrm{Zn}^{2+}}{\longrightarrow} \mathrm{HO}_{2}^{-}+\mathrm{O}_{2} \\
& \mathrm{HO}_{2}^{-}+\mathrm{O}_{3} \stackrel{\mathrm{Zn}^{2+}}{\longrightarrow} \mathrm{HO}_{2}^{*}+\mathrm{O}_{3}^{-} * \\
& \mathrm{HO}_{2} * \stackrel{\mathrm{Zn}^{2+}}{\longrightarrow} \mathrm{H}^{+}+\mathrm{O}_{2}^{-} * \\
& \mathrm{O}_{2}^{-} *+\mathrm{H}^{+} \stackrel{\mathrm{Zn}^{2+}}{\longrightarrow} \mathrm{HO}_{2}^{*} \\
& 2 \mathrm{HO}_{2}^{*}+\stackrel{\mathrm{Zn}^{2+}}{\longrightarrow} \mathrm{H}_{2} \mathrm{O}_{2}+\mathrm{O}_{2} \\
& \mathrm{H}_{2} \mathrm{O}_{2}+\mathrm{O}_{2}^{-} * \stackrel{\mathrm{Zn}^{2+}}{\longrightarrow} \mathrm{OH}^{*}+\mathrm{OH}^{-}+\mathrm{O}_{2}
\end{aligned}
$$

Maximum about $90 \%$ and almost $100 \%$ removal of COD and color were gained at $\mathrm{COD} / \mathrm{Zn}^{2+}(\mathrm{g} / \mathrm{g})$ ratio of $1: 6$ and $\mathrm{pH} 4$ for reaction time of $150 \mathrm{~min}$ and $180 \mathrm{~min}$, respectively. However, the decline of precentage COD removal over 150 min reaction time might due to the saturation of ozon at reaction time of $150 \mathrm{~min}$. Since landfill lechate constitutes various organic materials, Thus, the optimal experimental conditions for the treatment of stabilized anaerobic landfill leachate on the removal of COD (90\%) and color (almost $100 \%$ ) could be determined as $\mathrm{COD} / \mathrm{Zn}^{2+}(\mathrm{g} / \mathrm{g})$ ratio of $1: 6$, $\mathrm{pH} 4$ and reaction time $180 \mathrm{~min}$. Table 2 shows the removal of COD and color from stabilized anaerobic landfill leachate using various treatment process. Based on the data found in literature, it can be concluded that the $\mathrm{O}_{3} / \mathrm{ZnSO}_{4}$ is the most effective treatment process for the removal of COD and color from the stabilized anaerobic landfill leachate. Abu Amr et al. (2013) obtained $72 \%$ and 93\% COD and color removal, respectively, using persulphate assisted ozonation process. Further, $65 \%$ and $98 \%$ COD and color 
removal were gained, respectively, using Fenton reagent assisted ozonation process. Abu Amr et al., (2016) achieved $80 \%$ removal from COD using Ozone $/ \mathrm{ZrCl}_{4}$ process for leachate treatment. Wherein, about $90 \%$ and almost 100 removal of COD and color removal, respectively were gained in the present study using zinc sulphate assisted ozonation process. Thus, the performance of process $\left(\mathrm{O}_{3} / \mathrm{ZnSO}_{4}\right.$ can be considered is one of the efficient process for treating stabilized leachate treatment. In order to evaluate the performance of combined ozone and $\mathrm{ZnSO}_{4}$, additional experiments for ozone alone and $\mathrm{ZnSO} 4$ alone were perfumed at different $\mathrm{pH}$ levels (Table 2). The performance of ozone alone is week, although $\mathrm{ZnSO}_{4}$ alone achieved significant removal compared to ozone alone, however, the performance of combined ozone and ZnSO4 was higher than ozonation and coagulation separately. Moreover, the current treatment process considered not efficient for $\mathrm{NH}_{3}-\mathrm{N}$ removal from landfill leachate. Abu Amr et al., (2013) reported that ozone alone is not efficient for ammonia removal from leachate, while the performance of both $\mathrm{O}_{3} /$ Fenton and $\mathrm{O}_{3}$ /Persulfate for ammonia removal was higher.

Table 2. Comparing the performance $\mathrm{Zn} /$ ozone oxidation of techniques with other advanced oxidation applications for the treatment of stabilized leachate

\begin{tabular}{|c|c|c|c|c|c|c|}
\hline & \multirow[b]{2}{*}{ Experimental conditions } & \multicolumn{2}{|c|}{ COD } & \multicolumn{2}{|c|}{ Color } & \multirow[t]{2}{*}{ References } \\
\hline & & $\begin{array}{l}\text { Initial } \\
\text { (mg/L) }\end{array}$ & $\begin{array}{l}\text { Removal } \\
\text { (\%) }\end{array}$ & $\begin{array}{l}\text { Initial } \\
\text { (Pt.Co) }\end{array}$ & $\begin{array}{l}\text { Removal } \\
\text { (\%) }\end{array}$ & \\
\hline $\begin{array}{l}\text { Persulfate } \\
\left(\mathrm{S}_{2} \mathrm{O}_{8}{ }^{2-}\right)\end{array}$ & $\begin{array}{c}\mathrm{RT}: 240 \mathrm{~min}, \mathrm{pH}=8.5, \mathrm{COD} / \mathrm{S}_{2} \mathrm{O}_{8}{ }^{2-} \text { ratio }(1 \mathrm{~g} / 7 \mathrm{~g}) \\
\text { Rotation: } 350 \mathrm{rpm}, \text { Temp. } 28^{\circ} \mathrm{C}\end{array}$ & 2480 & 39 & 3450 & 55 & $\begin{array}{l}\text { Abu Amr et al., } \\
\text { (2013) }\end{array}$ \\
\hline Fenton & $\begin{array}{c}\mathrm{RT}: 120 \mathrm{~min}, \mathrm{pH}=3,0.05 \mathrm{~mol} \mathrm{~L}^{-1} \mathrm{H}_{2} \mathrm{O}_{2} \\
\text { and } 0.05 \mathrm{~mol} \mathrm{~L}^{-1} \mathrm{Fe}^{2+}\end{array}$ & 2180 & 55 & 4100 & 71 & $\begin{array}{l}\text { Abu Amr and } \\
\text { Aziz (2012) }\end{array}$ \\
\hline Fenton+ Ozone & $\begin{array}{c}\text { RT: } 120 \mathrm{~min}, \mathrm{pH}=3,0.5 \mathrm{~mol} \mathrm{~L}{ }^{-1} \mathrm{H}_{2} \mathrm{O}_{2} \text { and } 0.05 \mathrm{~mol} \\
\mathrm{~L}^{-1} \mathrm{Fe}^{2+}+\mathrm{RT}: 60 \mathrm{~min}, \mathrm{pH}=7, \mathrm{O}_{3}: 80 \mathrm{~g} / \mathrm{m}^{3}\end{array}$ & 2180 & 58 & 4100 & 95 & $\begin{array}{l}\text { Abu Amr and } \\
\text { Aziz (2012) }\end{array}$ \\
\hline $\begin{array}{l}\text { Persulfate + } \\
\text { Ozone }\end{array}$ & $\begin{array}{c}\text { RT: } 240 \mathrm{~min}, \mathrm{pH}=8.5, \mathrm{COD}_{0} / \mathrm{S}_{2} \mathrm{O}_{8}{ }^{2-} \text { ratio }(1 \mathrm{~g} / 7 \mathrm{~g}) \\
\left.\text { Rotation: } 350 \mathrm{rpm}, \mathrm{Temp} .28^{\circ} \mathrm{C}\right)+(\mathrm{RT}: 60 \mathrm{~min} \\
\mathrm{O}_{3}: 80 \mathrm{~g} / \mathrm{m}^{3} \mathrm{pH}=8.5\end{array}$ & 2480 & 55 & 3450 & 86 & $\begin{array}{c}\text { Abu Amr et al., } \\
\text { (2013) }\end{array}$ \\
\hline Fenton / Ozone & $\begin{array}{c}05 \mathrm{~mol} \mathrm{~L}^{-1} \mathrm{H}_{2} \mathrm{O}_{2} \text { and } 0.05 \mathrm{~mol} \mathrm{~L}^{-1} \mathrm{Fe}^{2+}, \mathrm{RT}: 90 \mathrm{~min}, \\
\mathrm{pH}=7, \mathrm{O}_{3}: 80 \mathrm{~g} / \mathrm{m}^{3}\end{array}$ & 2180 & 65 & 4100 & 98 & $\begin{array}{l}\text { Abu Amr and } \\
\text { Aziz (2012) }\end{array}$ \\
\hline Ozone/Persulfate & $\begin{array}{c}\text { RT: } 210 \mathrm{~min}, \mathrm{pH}=10, \mathrm{COD}_{0} / \mathrm{S}_{2} \mathrm{O}_{8}{ }^{2-} \text { ratio }(1 \mathrm{~g} / 7 \mathrm{~g}) \\
\mathrm{O}_{3}=80 \mathrm{~g} / \mathrm{m}^{3}\end{array}$ & 2480 & 72 & 3450 & 93 & $\begin{array}{c}\text { Abu Amr et al., } \\
(2013)\end{array}$ \\
\hline $\mathrm{ZrCl}_{4}$ & $\begin{array}{c}1 / 2 \mathrm{~g} / \mathrm{g} \mathrm{COD}_{0} / \mathrm{ZrCl}_{4}, \mathrm{pH} 6.250 \mathrm{rpm} \text {. Rapid mixing } \\
\text { at } 5 \mathrm{~min} \text {, followed by } 60 \mathrm{rpm} \text { for } 30 \text { min (slow } \\
\text { mixing) }\end{array}$ & 3125 & 22 & 12474 & 48 & \multirow[t]{2}{*}{$\begin{array}{c}\text { Abu Amr et al., } \\
(2016)\end{array}$} \\
\hline $\mathrm{ZrCl}_{4} /$ Ozone & $\begin{array}{c}\text { 1/2 g zirconium tetrachloride dosage } \\
\left(\mathrm{COD}_{0} / \mathrm{ZrCl} 4\right), \mathrm{pH} 6, \mathrm{RT}: 90 \mathrm{~min} \text { and } \mathrm{O}_{3}=27 \mathrm{~g} / \mathrm{m}^{3}\end{array}$ & 3125 & 80 & 12474 & 99 & \\
\hline Ozone alone & $\mathrm{RT}: 60 \mathrm{~min}, \mathrm{O}_{3}: 27 \mathrm{~g} / \mathrm{m}^{3} \mathrm{pH}=8.5$ & 3200 & 15 & 16000 & 44 & \multirow{9}{*}{$\begin{array}{l}\text { Current } \\
\text { treatment } \\
\text { process }\end{array}$} \\
\hline Ozone alone & $\mathrm{RT}: 60 \mathrm{~min}, \mathrm{O}_{3}: 27 \mathrm{~g} / \mathrm{m}^{3} \mathrm{pH}=7$ & 3200 & 13 & 16000 & 41 & \\
\hline Ozone alone & $\mathrm{RT}: 60 \mathrm{~min}, \mathrm{O}_{3}: 27 \mathrm{~g} / \mathrm{m}^{3} \mathrm{pH}=4$ & 3200 & 9 & 16000 & 27 & \\
\hline Zinc Sulphat & $\mathrm{RT}: 60 \mathrm{~min}, \mathrm{pH}=6, \mathrm{ZnSO}_{4}$ dosage $\left.1 / 6 \mathrm{~g} / \mathrm{g} \mathrm{Zn} / \mathrm{COD}\right)$ & 3200 & 55 & 16000 & 76 & \\
\hline Zinc Sulphat & $\mathrm{RT}: 60 \mathrm{~min}, \mathrm{pH}=4, \mathrm{ZnSO}_{4}$ dosage $\left.1 / 6 \mathrm{~g} / \mathrm{g} \mathrm{Zn} / \mathrm{COD}\right)$ & 3200 & 52 & 16000 & 73 & \\
\hline Zinc Sulphat & $\mathrm{RT}: 60 \mathrm{~min}, \mathrm{pH}=9, \mathrm{ZnSO}_{4}$ dosage $\left.1 / 6 \mathrm{~g} / \mathrm{g} \mathrm{Zn} / \mathrm{COD}\right)$ & 3200 & 44 & 16000 & 63 & \\
\hline $\mathrm{ZnSO}_{4} /$ Ozone & $\begin{array}{c}\mathrm{RT}: 60, \mathrm{pH}=6, \mathrm{ZnSO}_{4} \text { dosage } 1 / 6 \mathrm{~g} / \mathrm{g} \mathrm{Zn} / \mathrm{COD} \mathrm{O}_{3}= \\
27 \mathrm{~g} / \mathrm{m}^{3}\end{array}$ & 3200 & 90 & 16800 & 100 & \\
\hline $\mathrm{ZnSO}_{4} /$ Ozone & $\begin{array}{c}\mathrm{RT}: 60, \mathrm{pH}=4, \mathrm{ZnSO}_{4} \text { dosage } 1 / 6 \mathrm{~g} / \mathrm{g} \mathrm{Zn} / \mathrm{COD} \mathrm{O}_{3}= \\
27 \mathrm{~g} / \mathrm{m}^{3}\end{array}$ & 3200 & 76 & 16800 & 87 & \\
\hline $\mathrm{ZnSO}_{4} /$ Ozone & $\begin{array}{c}\mathrm{RT}: 60, \mathrm{pH}=9, \mathrm{ZnSO}_{4} \text { dosage } 1 / 6 \mathrm{~g} / \mathrm{g} \mathrm{Zn} / \mathrm{COD} \mathrm{O}_{3}= \\
27 \mathrm{~g} / \mathrm{m}^{3}\end{array}$ & 3200 & 68 & 16800 & 79 & \\
\hline
\end{tabular}

\section{*Reaction time}

\section{Conclusion}

The study evaluated the performance of combined ozonation with $\mathrm{ZnSO}_{4}$ for the landfill leachate treatment. The optimum conditions of $\mathrm{O}_{3} / \mathrm{ZnSO}_{4}$ oxidation was obtained at $\mathrm{ZnSO}_{4}$ dosage, $\mathrm{pH}$ variation, and ozonation time. Ozone alone only achieved $4 \%$ and $22 \%$ removal for COD and color, respectively, which revealed that ozone alone is not sufficient for leachate treatment. The combined ozone and $\mathrm{ZnSO}_{4}$ improved the removal of COD and color from $4 \%$ to $90 \%$ and from $22 \%$ to $99 \%$, respectively. Although $\mathrm{ZnSO}_{4}$ achieved better removal in COD (65\%) and color (86\%), however, the combined $\left(\mathrm{O}_{3} / \mathrm{ZnSO}_{4}\right)$ treatment process improved the removal efficiencies of organics during the ozonation of the leachate.

\section{Acknowledgment}

This work is funded by the Ministry of Education Malaysia under FRGS grant scheme (Grant No.203/PAWAM/6071280) and Universiti Sains Malaysia under Iconic grant scheme (Grant no. 1001/CKT/870023) for research associated with the Solid Waste Management Cluster, Engineering Campus, Universiti Sains Malaysia.

\section{References}

Abu Amr S.S, Zakaria S.T.F. and Aziz H.A. (2016), Performance of combined ozone and zirconium tetrachloride in stabilized landfill leachate treatment, J Mater Cycles Waste Manag, DOI $10.1007 / \mathrm{s} 10163-016-0524-\mathrm{x}$ 
Abu Amr S.S and Aziz H.A. (2012), New treatment of stabilized leachate by ozone/Fenton in the advanced oxidation process, Waste Management, 32, $1693-1698$

Abu Amr S.S., Aziz H.A., Adlan M.N. and Bashir M.J.K. (2013), Pretreatment of stabilized leachate using Ozone/Persulfate oxidation process, Chemical Engineering Journal, 221, $492-499$.

APHA, WPCF, AWWA (2005) Standard Methods for the Examination of Water and Wastewater, 21st ed., American Public Health Association (APHA), Washington, DC,

Aziz S.Q., Aziz H.A., Yusoff M.S., Bashir M.J.K. and UmarM. (2010), Leachate characterization in semi-aerobic and anaerobic sanitary landfills: A comparative study, J. Environ. Manage., 12, 2608-2614.

Azmi N.B., Bashir M.J.K., Sethupathi S., Aun N.C. and Lam G.C. (2016), Optimization of preparation conditions of sugarcane bagasse activated carbon via microwave-induced $\mathrm{KOH}$ activation for stabilized landfill leachate remediation, Env. Earth Sci., 75, 1-11.

Baig S. and Liechti P.A. (2001), Ozone treatment for biorefractory COD removal, Water Sci. Technol., 43, 197-204.

Bashir M.J.K., Aziz H.A. and Yusoff M.S. (2011), New sequential treatment for mature landfill leachate by cationic/anionic and anionic/cationic processes: Optimization and comparative study, J. Hazard Mater, 186, 92-102.

Bashir M.J.K., Aziz H.A., Abu Amr S.S., Sethupathi S., Ng C.A. and Lim J.W. (2015), The competency of various applied strategies in treating tropical municipal landfill leachate, Desalination and Water Treatment, 54, 2382-2395.

Bila D.M., Montalvao A.F., Silva A.C. and Dezotti M. (2005), Ozonation of landfill leachate: evaluation of toxicity removal and biodegrability improvement, J. Hazard. Mater. B, 117, 235-242.

Block P.A., Brown R.A. and Robinson D. (2004), Novel activation technologies for sodium persulfate in situ chemical oxidation, 4th Int. Conf. on the Remediation of Chlorinated and Recalcitrant Compounds, Battelle, Monterey, CA

Brown P.L., Curti E., Grambow B. and Ekberg C., 2005. Chemical thermodynamics of zirconium, OECD Nuclear Energy Agency, Data Bank, Issy-les-Moulineaux, France, 524.

Chen K.C. and Wang Y.H. (2014), The effects of Fe-Mn oxide and $\mathrm{TiO}_{2} / \mathrm{a}-\mathrm{Al}_{2} \mathrm{Oon}$ the formation of disinfection by-products in catalytic ozonation, Chemical Engineering Journal, 253, 84-92

Coca M., Pena M. and Gonzalez G. (2005), Variables affecting efficiency of molasses fermentation wastewater ozonation, Chemosphere, 60, 1408-1415.

Cong J., Wen G., Huang T., Deng L. and Ma J. (2015), Study on enhanced ozonation degradation of para-chlorobenzoic acid by peroxymonosulfate in aqueous solution, Chemical Engineering Journal, 264, 399-403.

Ghafari S., Aziz H.A. and Bashir M.J.K. (2010), The use of polyaluminum chloride and alum for the treatment of partially stabilized leachate: A comparative study, Desalination, 257, 110-116.

Goi A, Veressinina Y. and Trapido M, (2009) Combination of Ozonation and the Fenton Processes for Landfill Leachate Treatment: Evaluation of Treatment Efficiency, Ozone: Science \& Engineering, 31, 28-36.

Hagman M., Heander E. and Jansen J.L.C. (2008), Advanced oxidation of refractory organics in leachate-potential methods and evaluation of biodegradability of the remaining substrate, Environ. Technol., 29, 941-946.

Hu Z., Chandrana K., Smetsa B.F. and Grassob D. (2002), Evaluation of a rapid physical-chemical method for the determination of extant soluble COD, Water Research, 36, 617-624.

Huang S.S, Diyamandoglu V. and Fillos J. (1993), Ozonation of leachates from aged domestic landfills, Ozone: Sci. Eng., 15, 433-444.

Langlais B., Reckhow D.A. and Brink D.R. (1991), Ozone in Water Treatment: Application and Engineering, first ed. Lewis Publishers Inc., Chelsea, MI.

Lenntech, Water treatment solution, Ozone decomposition, Technical University of Delft, the Netherlands, 3/8/2016.http://www.lenntech.com/library/ozone/decompo sition/ozone-decomposition.htm

Li W., Zhou O. and Hua T. (2010), Removal of Organic Matter from Landfill Leachate by Advanced Oxidation Processes: A Review, International Journal of Chemical Engineering, doi.org/10.1155/2010/270532

Mehrjouei M., Müller S. and Möller D. (2015), A review on photocatalytic ozonation used for the treatment of water and wastewater, Chemical Engineering Journal, 263, 209-219.

Rivas F.J., Beltran F., Gimeno O., Acedo B. and Carvalho F. (2003), Stabilized leachates: ozone-activated carbon treatment and kinetics, Water Research, 37, 4823-4834.

Schiopu A.M. and Gavrilescu M. (2010), Options for the Treatment and Management of Municipal Landfill Leachate: Common and Specific Issues, Clean: Soil, Air, Water, 12, 1101-1110.

Saif U.R.M., Azeem K., Sadaf L., Mehmood C.T., Tariq M. and Mehmood S. (2012), Color and COD removal from poultry litter leachate using an ozonation process, Environmental Engineering \& Management Journal, 11(8), 1467-1470.

Shehzad A., Bashir M.J.K., Sethupathi S. and Lim J-W. (2015), An overview of heavily polluted landfill leachate treatment using food waste as an alternative and renewable source of activated carbon, Process Safety and Environmental Protection, 98, 309-318.

Sun Q., Li L., Yan H., Hong X., Hui K.S. and Pan Z. (2014), Influence of the surface hydroxyl groups of $\mathrm{MnO} / \mathrm{SBA}-15$ on heterogeneous catalytic ozonation of oxalic acid, Chemical Engineering Journal, 242, 348-356.

Tengrui L., AL-Harbawi A.F., Bo L.M. and Jun Z. (2007), Characteristics of nitrogen removal from old landfill leachate by sequencing batch biofilm reactor, J. Appl. Sci., 4, 211-214.

Tizaoui C., Bouselmi L., Mansouri L. and Ghrabi A. (2007), Landfill leachate treatment with ozone and ozone/hydrogen peroxide systems, Journal of Hazardous Materials, 140, 316-324.

Zawawi M.H. and Syafalni Abustan I. (2011), Detection of groundwater aquifer using resistivity imaging profiling at Beriah Landfill Site, Perak, Malaysia, Journal of Advanced Material Research, 250-253, 1852-1855.

Zhu S.N., Hui K.N., Hong X. and Hui K.S. (2014), Catalytic ozonation of basic yellow 87 with a reusable catalyst chip, Chemical Engineering Journal, 242, 180-186. 